\title{
CORRESPONDENCE
}

\section{RE.: HUMAN OCULAR SPARGANOSIS IN SOUTHERN BRAZIL}

Dear Editor,

I read the recent publication on sparganosis with a great interest ${ }^{1}$. MENTZ et al. presented a case with long term periocular moveable inflammatory masses $^{1}$. This is very interesting. Not like the case of gnathostomiasis, the moveable swelling mass is not a common presentation of sparganosis. In a series of sparganosis in Thailand, there is no case with history of migration swelling lesion ${ }^{2}$. I agree that this is a case of sparganosis but the question is whether there is no other concomitant parasitic infestation and what leads to the moving swelling lesion if there is no concomitant infestation.

Viroj WIWANITKIT

Wiwanitkit House, Bangkhae, Bangkok Thailand 10160

Email:wviroj@yahoo.com

Phone: 6624132436

\section{REFERENCES}

1. Mentz MB, Procianoy F, Maestri MK, Rott MB. Human ocular sparganosis in southern Brazil. Rev Inst Med Trop Sao Paulo. 2011;53:51-3.

2. Wiwanitkit V. A review of human sparganosis in Thailand. Int J Infect Dis. 2005;9:312-6. 